\section{Media Publikasi Promosi Kesehatan Indonesia The Indonesian Journal of Health Promotion}

\title{
Faktor - Faktor Keputusan Pembelian Obat Anti Hipertensi Pada Pelayanan Non Resep Di Apotek Wilayah Kecamatan Palu Selatan
}

\author{
Factor of Decision Factor of Purchase of Antihypertension Drug Non Prescription Service \\ at Pharmacy District of Palu South City
}

\author{
${ }^{\left(1^{*}\right)}$ Firdawati Amir Parumpu, ${ }^{(2)}$ Afriani Kusumawati \\ ${ }^{\left(1^{*}-2\right)}$ Akademi Farmasi Tadulako Farma Palu \\ ${ }^{\left(1^{*}\right)}$ firdaamirparumpu@gmail.com \\ (*) Corresponding Author
}

\begin{abstract}
Abstrak
Saat ini, obat keras dapat dibeli dengan mudah di apotek walau tanpa resep dokter. Salah satu Obat keras yang diperjual belikan di apotek tanpa resep dokter adalah obat-obat antihipertensi.Tujuan dari penelitian ini adalahuntuk mengetahui studi penggunaan antihipertensi pada pelayanan non resep di apotek di wilayah kecamatan Palu Selatan Kota Palu, serta alasan masyarakat dalam mengkonsumsi antihipertensi tanpa resep dokter.Penelitian ini merupakan penelitian deskriptif, yaitu menggambarkan dan menginterpretasikan studi penggunaan antihipertensi pada pelayanan non resepdi apotek di wilayah kecamatan Palu Selatan Kota Paludengan menggunakan metode survey.Berdasarkan hasil penelitian diketahui bahwa Sebagian besar masyarakat di wilayah kecamatan Palu Selatan yaitu sebanyak $89 \%$ pernah menggunakan antihipertensi tanpa resep, dengan tingkat pengetahuan masyarakat rata-rata $85,57 \%$ dan dikategorikan sebagai tingkat pengetahuan tinggi.Alasan masyarakat di wilayah kecamatan Palu Selatan menggunakan antihipertensi tanpa resep karena merasa cocok pada pengobatan sebelumnya.
\end{abstract}

Kata Kunci : Pelayanan; apotek; pembelian; antihipertensi; keputusan

\begin{abstract}
Currently, hard drugs can be purchased easily in pharmacies even without a doctor's prescription. One of the hard drugs traded without a Doctor's prescription is an antihipertensy drugs. The purpose of this research is to know the Factor of decision factor of purchase of antihypertension drug at non prescription service at pharmacy of district of Palu Southern palu city.This research is descriptife research that describe and interpretasion Factor of decision factor of purchase of antihypertensive drug at non prescription service at pharmacy of area of sub district of south palu by using survey methodeBased on the results of research known that most people in the region of souther Palu district that is as much as $89 \%$ never use antihipertensy without prescription ith level of knowledge o the average community and categorized as a high level of knowledge.The reason people in the are of southern Palu disctrict using ant-hypertension without a prescription because iut feels appropiate on previous treatment.
\end{abstract}

Keywords: Service; apothecary; buying; antihipertension; decision 


\section{PENDAHULUAN}

Kesehatan merupakan hal terpenting dalam kehidupan manusia, karena dengan tubuh sehat setiap individu mampu menjalankan segala aktivitas kehidupannya sehari-hari dengan baik. Menurut Undang-Undang Republik Indonesia Nomor 36 tahun 2009 tentang Kesehatan, dikatakan bahwa kesehatan merupakan suatu keadaan sejahtera dari badan, jiwa, dan sosial yang memungkinkan setiap orang hidup produktif secara sosial dan ekonomis. Hipertensi secara umum didefinisikan sebagai tekanan sistolik lebih dari $140 \mathrm{mmHg}$ dan tekanan diastolik lebih dari $90 \mathrm{mmHg}$. Hipertensi merupakan salah satu faktor risiko yang paling berpengaruh terhadap kejadian penyakit jantung dan pembuluh darah. Tekanan darah tinggi atau hipertensi merupakan masalah kesehatan di dunia yangsangat penting dikarenakan angka kejadiannya yang tinggi. Prevalensi tekanan darah tinggi meningkat seiring dengan peningkatan usia (1).

Saat ini obat keras dapat dibeli dengan mudah di apotek walau tanpa resep dokter, salah satu alasannya adalah persaingan bisnis antar apotek yang ujungnya bertujuan untuk meningkatkan omset apotek. Adanya peluang yang diberikan oleh apotek yang menjual obat keras secara bebas dan lemahnya peraturan serta sanksi yang ada menyebabkan terjadinya peningkatan dalam penggunaan obat keras tanpa resep dokter. Upaya masyarakat melakukan pengobatan sendiri dinilai seperti pedang bermata dua. Di satu sisi akan mengurangi beban pelayanan di Puskesmas atau Rumah sakit (2). Di sisi lain bila obat yang digunakan tidak diimbangi dengan pengetahuan yang memadai,maka akan menimbulkan hal-hal yang tidak di inginkan. Menurut data yang diperoleh dari Badan Pusat Statistik (BPS) Sulawesi Tengah Tahun 2016, terdapat 68.385 jumlah penduduk di kecamatan Palu Selatan, kota Palu. Sedangkan menurut data yang diperoleh dari Dinas Kesehatan Provinsi Sulawesi Tengah, terdapat 65 sarana pelayanan kesehatan Apotek di kecamatan Palu Selatan kota Palu.

Dari data tersebut, maka penulis tertarik untuk melakukan penelitian tentang faktor- faktor keputusan pembelian obat Antihipertensi pada pelayanan non resep di apotek-apotek yang terdapat di kecamatan Palu Selatan, kota Palu, Sulawesi Tengah. Penelitian ini bertujuan untuk Untuk mengetahui faktor-faktor keputusan pembelian obat antihipertensi pada pelayanan non resep di Apotek wilayah Kecamatan Palu Selatan

\section{METODE}

Penelitian ini merupakan penelitian deskriptif, Waktu penelitian dilakukan selama 5 bulan dan penelitian ini bertempat di Apotek -apotek di wilayah Kecamatan Palu selatan kota Palu. Kriteria inklusi dalam penelitan ini yaitu (a) masyarakat wilayah Kecamatan Palu Selatan yang mnegkonsumsi obat antihipertensi tanpa resep dokter, (b) masyarakat wilayah Kecamatan Palu Selatan Kota Palu berumur lebih dari 17- 70 tahun. Kriteria ekslusi dalam penelitian ini yaitu (c) masyarakat wilayah Kecamatan Palu Selatan yang mengkonsumsi obat antihipertensi dengan resep dokter, masyarakat wilayah Kecamatan Palu Selatan Kota Palu yang berumur di bawah 17 tahun dan di atas 70 tahun. Pengambilan data dilakukan dengan pengambilan kuesioner berisi butir pertanyaan yang telah dilakukan pengkodean, dan kemudian dilakukan analisa data dengan cara data yang diperoleh dari penelitian kemudian dianalisis secara deskriptif dan hasilnya disajikan dalam bentuk tabel dan narasi.

\section{HASIL}

Dari penelitian karakteristik responden berdasarkan umur, dapat diketahui bahwa sebagian besar dari jumlah 100 responden di wilayah Kecamatan Palu Selatan Kota Palu masuk dalam kategori produktif dengan perolehan nilai sebesar $63 \%$ produktif dan $37 \%$ non produktif. Dari keseluruhan hasil penelitian karakteristik responden berdasarkan jenis kelamin dapat diketahui bahwa sebagian besar responden pengguna antihipertensi di wila- 
yah Kecamatan Palu Selatan Kota Palu yang ditemui adalah laki-laki sebanyak 53\% dan sisanya perempuan sebanyak 47\%. Sementara berdasarkan tingkat pendidikan, dapat diketahui bahwa sebagian besar responden di wilayah Kecamatan Palu Selatan Kota Palu, sudah mengenyam pendidikan yang cukup baik dengan hasil yang diperoleh yaitu, SD 3\%, SMP 3\%, SMA 42\%, dan Sarjana sebanyak 52\%.

Adapun data hasil pengamatan yang diambil melalui kuesioner yaitu sebanyak $43 \%$ responden menjawab A, 12\% menjawab B, dan sebanyak 45\% menjawab C. Dari hasil tersebut dapat diketahui bahwa sebagian besar responden yaitu sebanyak $45 \%$ menggunakan antihipertensi berdasarkan pengalaman sebelumnya, dan $43 \%$ responden menggunakan antihipertensi berdasarkan anjuran dari dokter, serta hanya 12\% responden yang menggunakan antihipertensi berdasarkan anjuran Apoteker. Dapat disimpulkan bahwa pengguaan anti hipertensi tanpa resep berdasarkan anjuran tenaga kesehatan lebih besar. Pada pertanyaan selanjutnya sebanyak $73 \%$ responden menjawab A, sebanyak $2 \%$ responden menjawab B, dan sebanyak $25 \%$ responden menjawab C. Dari hasil tersebut dapat diketahui bahwa sebagian besar responden yaitu sebanyak 73\% tidak pernah menggunakan resep antihipertensi yang sudah pernah dilayani. Pada pertanyaan selanjutnya sebanyak 97\% responden menjawab A, 3\% responden menjawab B. Dari hasil tersebut dapat diketahui bahwa sebagian besar responden yaitu sebanyak $97 \%$ menggunakan kembali antihipertensi tanpa resep dokter dengan alasan pengobatan sebelumnya efektif. sebanyak $98 \%$ responden menjawab A, sebanyak $2 \%$ responden menjawab B. Dari hasil pertanyaan selanjutnya dapat diketahui bahwa sebagian bsar responden yaitu sebanyak 98\% menggunakan anti hiperetensi tanpa resep dokter karena merasa cocok pada pemakaian sebelumnya. Berdasarkan hasil hitungan kuisioner yang diperoleh dapat dilihat tanggapan responden yang mengetahui dengan baik tentang hipertensi dan penggunaan antihipertensi yaitu sebanyak $85,57 \%$. Berdasarkan pengukuran tingkat pengetahuan $85,57 \%$ masuk dalam kategori tinggi.

Penelitian ini juga menemukan bahwa ada hubungan signifikan antara daerah tempat tinggal responden sebagai proxy dari agama dengan niat melakukan hubungan seksual secara statistik ( $\mathrm{p}$-value $<0.01$ ). Responden yang tinggal di daerah dengan mayoritas penduduk Kristiani mempunyai persentase tertinggi $(41,8 \%)$ berniat melakukan hubungan seksual ketika dibandingkan dengan mereka yang tinggal di daerah lainnya; daerah mayoritas Hindu sebesar 34,2\% dan daerah gabungan mayoritas Muslim dan Kristiani 33.1\%. Pada daerah mayoritas Muslim, persentase berniat melakukan hubungan seksual terkecil yaitu hanya $18,9 \%$. Ada hubungan yang signifikan pula antara status tempat tinggal dengan niat melakukan hubungan seksual ( $p$-value $<0.05$ ). Mereka yang tinggal di daerah perkotaan memiliki persentase yang lebih tinggi ingin melakukan hubungan seksual dibandingkan dengan mereka yang tinggal di pedesaan $(22.7 \%$ berbanding $19,0 \%)$.

\section{PEMBAHASAN}

Antihipertensi merupakan salah satu jenis obat- obat keras, dimana pada pasal 3 ayat 1 dikatakan bahwa obat keras tidak boleh digunakan secara pribadi tanpa menggunakan resep dokter. Penelitian ini dilakukan di 39 Apotek wilayah palu selatan selama 5 bulan mengenai faktor- faktor keputusan pembelian obat Anti hipertensi pada pelayanan non resep di Apotek wilayah kecamatan Palu selatan. Jenis data yang diperoleh peneliti dari alat ukur dalam bentuk kuisioner yang memuat pernyataan bersifat terbuka.Berdasarkan rumus slovin Penarikan sampel berdasarkan jumlah penduduk wilayah palu selatan yaitu didapat 100 responden, dan dilakukan kembali penarikan sampel ratarata yaitu didapatkan hasil 3 responden tiap Apotek. Responden termasuk dalam kriteria inklusi masyarakat wilayah palu selatan yang mengkonsumsi obat tanpa resep dan masyarakat wilayah kecamatan palu selatan berumur lebih dari 17-70 tahun.

Dari penelitian yang telah dilakukan kepada masyarakat dengan total keseluruhan responden sebanyak 100 di 
wilayah Kecamatan Palu Selatan, Kota Palu, diperoleh hasil persentase tanggapan responden mengenai hipertensi dan penggunaan hipertensi yaitu yang menjawab benar sebanyak $85,57 \%$ dan masuk dalam kategori tingkat pengetahuan tinggi. Tingginya tingkat pengetahuan masyarakat di wilayah kecamatan Palu Selatan Kota Palu, dipengaruhi oleh beberapa faktor, diantaranya faktor umur dan faktor tingkat pendidikan. Semakin tinggi umur seseorang maka semakin banyak pula pengetahuan yang diperoleh (3). Sementara untuk faktor tingkat pendidikan, semakin tinggi pendidikan seseorang, maka semakin mudah menerima informasi sehingga makin banyak pula pengetahuan yang dimiliki. Dimana sebagian besar masyarakat yang membeli obat hipertensi tanpa resep mengetahui bahwa hipertensi digunakan untuk menurunkan tekanan darah, dan masyarakat mengetahui faktor apa saja yang dapat meningkatkan tekanan darah (4).

Hasil persentase tanggapan responden mengenai hipertensi dan penggunaan hipertensi yang menjawab salah yaitu sebanyak 14,43\% dapat disimpulkan bahwa dapat dipengaruhi oleh beberapa faktor diantaranya faktor umur berdasarkan hasil persentase usia non produktif sebesar 37\%. Semakin bertambah umur seseorang maka akan mengalami penurunan fisik, biologis dan psikologi. Hal ini mempengaruhi daya tangkap dan pola pikir seseorang (5). Faktor lainnya disebabkan oleh tingkat pendidikan berdasarkan hasil persentase karakteristik responden berdasarkan pendidikan yaitu sebanyak 3\% masyarakat palu selatan berpendidikan SD dan SMP dimana kita ketahui pada pendidikan SD dan SMP Untuk pengetahuan tentang penyakit tidak pernah diajarkan. Maka dapat disimpulkan semakin tinggi pendidikan seseorang maka akan semakin mudah untuk memahami informasi tentang suatu hal. Dimana sebagian besar masyarakat palu selatan menyimpulkan bahwa obat hipertensi boleh digunakan hanya satu tablet saja jika diperlukan, dan obat hipertensi memiliki efek dan cara penggunaan yang sama. Dari hasil persentase jawaban responden terhadap faktor anjuran menggunakan anti hipertensi yaitu sebanyak 55\% berdasarkan anjuran tenaga kesehatan hal ini dipengaruhi oleh faktor adanya kesadaran masyarakat tentang perlunya informasi yang cukup tentang mengenai hipertensi dan penggunaan obat anti hipertensi. Hal ini dapat disimpulkan bahwa penggunaan antihipertensi berdasarkan anjuran tenaga kesehatan benar, tetapi menjadi salah ketika antihipertensi dibeli tanpa resep dokter, kenyataannya apoteker masih memberikan anjuran menggunakan dan melayani tanpa resep. Dan berdasarkan hasil persentase jawaban responden terhadap faktor alasan penggunaan ulang antihipertensi tanpa resep sebanyak 97\% dengan alasan pengobatan sebelumnya efektif. Hal ini dipengaruhi oleh faktor adanya sugesti masyarakat tentang pengobatan sebelumnya dengan antihipertensi memberikan hasil yang baik, sehingga jika digunakan kembali hasilnya tetap efektif. Dari hasil persentase jawaban responden terhadap faktor alasan pasien menggunakan antihipertensi tanpa resep yaitu 98\% masyarakat menjawab menggunakan antihipertensi tanpa resep dokter karena merasa cocok pada pemakaian sebelumnya. Walaupun hasilnya baik ini tidak dapat dibenarkan karena antihipertensi hanya dapat dibeli dengan menggunakan resep dan tidak semuanya tingkat hipertensi memberikan tanda dan gejala yang sama sehingga pengobatannya pun tidak dapat disamakan. Berdasarkan kriteria inklusi peneliti hanya mengambil 3 kelompok usia yaitu usia remaja, produktif dan non produktif, yaitu masyarakat yang berusia lebih dari 17 - 70 tahun. Karena sejak usia 17 tahun keatas penyakit hipertensi mulai mengintai usia remaja yang disebabkan salah satunya yaitu perubahan pola makan, makanan cepat saji dengan kandungan gula dan garam yang tinggi menjadi pemicu kasus antihipertensi pada usia remaja, dan pada lansia hampir semua mengalami hipertensi karena semakin tua seseorang makin berkurang elastisitas pembuluh darahnya (6). Dari keseluruhan hasil olah data tersebut dapat diketahui bahwa faktor- faktor keputusan pembelian obat antihipertensi pada pelayanan non resep di apotik dipengaruhi oleh beberapa faktor yaitu tingkat pengetahuan, faktor anjuran menggunakan antihipertensi, faktor pernah menggunakan resep anti hipertensi yang sudah pernah dilayani, faktor alasan penggunaan ulang antihipertensi tanpa resep. 
Pengetahuan masyarakat mengenai hipertensi dan penggunaan antihipertensi kecamatan palu selatan, kota palu sudah sangat baik. Tingginya pengetahuan masyarakat di pengaruhi oleh umur, dan faktor tingkat pendidikan. Sebagian besar masyarakat menggunakan anti hipertensi berdasarkan anjuran tenaga kesehatan, sebagian besar masyarakat tidak pernah menggunakan kembali resep anti hipertensi yang sudah dilayani, dan penggunaan ulang antihipertensi karena merasa cocok pada pengobatan sebelumnya.

\section{KESIMPULAN DAN SARAN}

Dari hasil peneitian yang telah dilakukan pada masyarakat di wilayah kecamatan Palu Selatan, dapat di tarik kesimpulan sebagai berikut : faktor- faktor keputusan pembelian obat Antihipertensi pada pelayanan non resep di apotik dipengaruhi oleh beberapa faktor yaitu tingkat pengetahuan 85,57\%, faktor anjuran menggunakan Anti hipertensi $65 \%$, faktor pernah menggunakan resep anti hipertensi yang sudah pernah dilayani sebanyak $27 \%$, faktor alasan penggunaan ulang antihipertensi tanpa resep $97 \%$.

\section{DAFTAR PUSTAKA}

1. Ridjab D a. Modifikasi Gaya Hidup dan Tekanan Darah. Majalah Kedokteran Indonesia. 2007;

2. Maqin RA. ANALISIS DISPARITAS PENDAPATAN ANTAR DAERAH DI JAWA BARAT. War Bappeda. 2005;

3. Fernandez BAM. Studi Penggunaan Antibiotik Tanpa Resep Di Kabupaten Manggarai dan Manggarai Barat NTT. Calyptra J Ilm Mhs Univ Surabaya Vol2 No2 Stud. 2013;

4. Sari CY. Menurunkan Tekanan Darah Tinggi. J Major. 2015;

5. Herlinah L, Wiarsih W, Rekawati E, Kunci: Keluarga K, Hubungan H, Keluarga D, et al. Hubungan Dukungan Keluarga Dengan Perilaku Lansia Dalam Pengendalian Hipertensi. J Keperawatan Komunitas. 2013;

6. Kurniawan A. Gizi seimbang untuk mencegah hipertensi. Seminar. 2012; 